\title{
Trends of Adjudication Cases in Malaysia
}

\author{
Quratul Ain Mazani *, Siti Suhaidah Sahab and Zulhabri Ismail ** \\ Faculty of Architecture, Planning and Surveying, Universiti Teknologi MARA, Shah Alam, Malaysia
}

\begin{abstract}
The construction industry is a fertile source of dispute. Payment disputes in the Malaysian construction industry are ancient issues that have been causing problems among construction players for decades. The settlement of disputes can be done by using the Alternative Dispute Resolution (ADR) in lieu of other alternatives or as a complement to Litigation. This paper is focused on Adjudication as a preferred dispute resolution method for the Malaysian construction industry. The enforcement of the Construction Industry Payment and Adjudication Act (CIPAA 2012) in 2014 is intended to provide swift dispute resolution and relief to unpaid construction industry claimants for work done, and facilitate cash flow in the construction industry as a whole. The purpose of this research is to establish the trends of adjudication cases that were intervened by the court within the period of April 2014 until February 2018, which is since the implementation of CIPAA 2012 in Malaysia. In order to determine a vast majority of matters that have been referred for adjudication under CIPAA 2012 and parties in dispute constitute the highest number of referrals, sixty-two court cases were identified. This research also reviewed previous case laws to identify the factors contributing to court referrals. Based on the review, most of adjudication cases in the Malaysian construction industry involve the Main contractor and Employer as dispute parties with the intention of challenging adjudication decisions as there has been excess of jurisdiction pursuant to Section 15 (d) applied by appellants together with the application enforcement of adjudication decision under Section 28 by respondents. The findings will be used as a platform to establish the dispute scenario of the Malaysian construction industry under the CIPAA 2012.
\end{abstract}

\section{Introduction}

The construction industry is facilitated by various disputes resolution methods due to its inherent nature which is very complex, involves relatively long project durations, is subject to many uncertainties, and is one of a kind. There are various types of disputes that may occur along a project's cycle, such as disputes arising from project delays, design errors which lead to additional payment, low contractor quality and workmanship, and others. As payment is said to be the lifeblood of the construction industry, payment disputes remain a major problem among construction players. Ramachandra and Rotimi [1] revealed that payment is the main subject matter of construction disputes which result in project delays, reduced profitability, and abandoned projects. Payment problems are still the main issue among construction players, more so payment from the client to the main contractor, either in the form of advance payment, progress payment or final payment [2]. Therefore, the construction industry is facilitated by various types of dispute resolution methods as a platform to mitigate the impact of disputes on projects. Disputes can be solved using Alternative Dispute Resolution methods (ADR), such as mediation, adjudication and arbitration which are aimed to achieve resolutions in a shorter time span, with fewer expenses and without the need for court intervention. Dispute settlement can also be done through a formal court process called Litigation. The use of adjudication as a rapid binding dispute resolution procedure for construction contracts has slowly spread around the world. Adjudication is the most widely used form of dispute resolution method in the Malaysian construction industry [3]. It also has been proven by statistics collected by the Asian International Arbitration Centre (AIAC) in 2017 as the principal institution that administers commercial arbitrations in Malaysia. According to AIAC (2018), the adjudication application statistics has increased in terms of registered matters since the implementation of the CIPAA 2012 in 2014. However, statistics published by the Malayan Law Journal showed that the number of adjudication cases brought to the court has also increased over the years. Consequently, this research will investigate the factors that contribute to court referrals in order to establish the pattern of adjudication cases referred to the court in the Malaysian construction industry under the CIPAA 2012

\section{Payment Defaults}

Payment is known as the lifeblood of a project, and it is vital for all parties involved in the construction industry. As mentioned by Judi et al. [2], payment defaults in the Malaysian construction industry have relatively

*Corresponding author: zulhabri@salam.uitm.edu.my**,quratulmazani@gmail.com * 
increased in number in recent years, and it has come into existence since the year 2000 [1]. The researchers further argued that some Malaysian contractors who are registered with CIDB Malaysia have experienced late payments and non-payment issues, either in governmentfunded projects or private-funded projects. Therefore, payment problems should be carefully assisted along the project cycle as the consequences of untimely payments can be costly, such as the inability of project completion within a specific time frame and increase in project cost which may, in turn, have major impacts on the project as a whole. The Malaysian culture or attitude is one of the major causes of late and non-payment in the Malaysian construction industry, followed by delays in certification by consultants, and paymasters' poor financial management [4]. Thus, intervention by third parties for resolution using methods such as adjudication is needed to reduce the possibility of factors that may lead to payment defaults. A good payment system is one of the pillars of successful projects. Inefficient payment systems may subject most projects to delay [5]. This shows that sound time management, with regards to the payment system, is crucial to ensure the smoothness of project delivery and it will affect all stakeholders such as the main contractor, subcontractors, suppliers, labour contractors and society. As payment problems are not new to the Malaysian construction industry, most project teams which comprise the director, project manager, engineers and others make delays in payment to the suppliers due to late payment from contractors. In the same time, project teams also face late payment problems, especially from private clients [6].

\section{Overview Of CIPAA 2012}

The Construction Industry Payment and Adjudication Act 2012 (CIPAA 2012) was gazetted on 22nd June, 2012 and effectively implemented on 15 April, 2014 a speedy dispute resolution mechanism with the aim to facilitate regular and timely payment, provide a mechanism for speedy dispute resolution through adjudication, provide remedies for the recovery of payment in the construction industry, and provide for connected and incidental matters [7]. Compared to litigation and arbitration, adjudication is less timeconsuming and uses lower expenses [8].

The concept of statutory adjudication through the enforcement of security of payment legislation in the Malaysian construction industry under CIPAA 2012 follows the successful implementations conducted in United Kingdom, Australia, New Zealand and Singapore as assistance to problems of payment defaults in the construction industry [9]. The primary objective of the Act is to address cash flow problems in the construction industry. It mitigates the pervasive and prevalent practice of conditional payment which is 'pay when paid, pay if paid' and decreases payment defaults by establishing a cheaper and speedier system of dispute resolution in the form of adjudication. In the interim, the parties still need to comply with the adjudication decision and pay the disputed amount, unless the decision stays through an application made to the High Court under Section 16. CIPAA 2012 identifies construction contracts which encompass both construction work contracts and consultancy services contracts [10]. It, therefore, affects both local and international contracts that fall within the ambit of the Act. The Asian International Arbitration Centre (AIAC) reported that 244 cases have been recorded in the first quarter of the year 2018. In the year 2017, 704 adjudication matters were registered, an increase from 447 cases registered in the year 2016. This shows that the CIPAA 2012 effectively works and payment disputes can be resolved as quickly as possible through fast and uncomplicated adjudication proceedings. The adjudication application statistics are shown in Table 1.

Table 1. The Registered and unregistered matters by the calendar year within1st January to 31st December (2014-2018)

\begin{tabular}{|c|c|c|}
\hline Timeframe & $\begin{array}{c}\text { No. of Registered } \\
\text { Matters }\end{array}$ & $\begin{array}{c}\text { No. of Unregistered } \\
\text { Matters }\end{array}$ \\
\hline $\begin{array}{c}\text { As of } \\
31 / 12 / 14\end{array}$ & 29 & - \\
\hline $\begin{array}{c}1 / 1 / 15- \\
31 / 12 / 15\end{array}$ & 181 & 13 \\
\hline $\begin{array}{c}1 / 1 / 16- \\
31 / 12 / 16\end{array}$ & 447 & 16 \\
\hline $\begin{array}{c}1 / 1 / 17- \\
31 / 12 / 17\end{array}$ & 704 & 7 \\
\hline $\begin{array}{c}1 / 1 / 18- \\
15 / 4 / 18\end{array}$ & 244 & 10 \\
\hline Total & 1605 & 46 \\
\hline
\end{tabular}

The AIAC also predicted that by the end of the year 2018, the number of cases referred to CIPAA 2012 adjudication is expected to reach up to 882 based on the trend of growth. However, the AIAC also expects that the number of CIPAA 2012 matters will slow down in the coming years as CIPAA 2012 provides rules for any payment issues that need to be followed by construction players. AIAC is also well aware of the overall changes in the industry as a result of the implementation of CIPAA 2012. As CIPAA 2012 is now widely accepted as a cheap and efficient way to resolve disputes, parties to agreements under which they need to pay other parties have generally shown an increase in their paying morale.

\section{CIPAA 2012's Impact On Payment Problems}

CIPAA 2012 has bright potential in eliminating payment issues between parties in the Malaysian construction industry [11]. The main significance of the new act is the facilitation of regular and timely payments of construction projects as cash flow is vital due to its role in the completion of work. Other than that, parties become more attentive to their payment obligations. Construction players agree with the primary objective of CIPAA 2012 which is to facilitate regular and timely payments of construction projects. Involved parties agree

*Corresponding author: zulhabri@salam.uitm.edu.my**,quratulmazani@gmail.com * 
that the enactment of CIPAA 2012 improves construction projects' cash flow. Previous research has identified six impacts of the CIPAA 2012's enforcement towards payment problems in the Malaysian construction industry, which are

i. Relief provisions to unpaid claimants for work done,

ii. Any withholding of payment needs to be settled within thirty (30) days from the receipt of invoice unless otherwise agreed,

iii. Confidential settlement of conflict among dispute parties,

iv. Prohibition of conditional payments,

v. Allowance of direct payment from the principal,

vi. Local culture or the attitude of late payment at the mercy of clients.

The statutory right to payment does not displace any contractual payment terms adopted by parties to the main contract or subcontract [12]. The Claimant who is the unpaid party may commence a process under CIPAA 2012 through the issuance of a payment claim as he is allowed to refer a payment dispute for adjudication under Section 5. Payment in CIPAA 2012's context refers to any payment for construction work done and consultancy services rendered arising under the express terms of a construction contract. Therefore, an adjudicator's decision is binding and has to be complied to until and unless the subject disputed is resolved through arbitration, litigation, agreement in writing, or is otherwise set aside by the Court under Section 15.

The winning party may apply to the High Court to enforce the Adjudication Decision as if it was a judgement or order from the High Court. Next, the respondent must pay the amount specified in the adjudication decision of the unevaluated claim within thirty (30) days from the receipt of invoice under Section 36 (4). Thus, the unpaid party may recover all payments in a short time period in order to finance the project. Moreover, parties in dispute are able to remain confidential as adjudication is not an open hearing, unlike litigation [13]. The proceeding is conducted privately and is ensured of its confidentiality as stated in Section 20. Agreed that a contractor may suspend or slow down the work's progress if the adjudicated amount is not paid either partly or fully [12]. It shows that the winning party may suspend performance or reduce the rate of progress of performance of the construction work or consultancy under the construction contract.

\section{Effectiveness Of CIPAA 2012 In Addressing Security Payment Problems In Malaysia}

The effectiveness of CIPAA 2012 is measured through the selection of 62 adjudication cases that have been intervened by the court within the period of April 2014 until February 2018 which is since the implementation of CIPAA in Malaysia. The selection was made based on The Malayan Law Journal Unreported (MLJU) as a series of unreported raw judgments, providing reports of cases from the Federal Court, the Court of Appeal and High Courts. It is in line with the objectives of the paper which are to identify the vast majority of matters that have been referred for adjudication under CIPAA 2012, the majority of claimants that have brought their disputes to CIPAA 2012 and the factors that contribute to the referrals made to the court.

Table 2. Adjudication cases with intervention by the court

\begin{tabular}{|c|c|c|c|c|}
\hline \multirow[b]{2}{*}{ Year } & \multicolumn{3}{|c|}{ Court Decision } & \multirow[b]{2}{*}{$\begin{array}{l}\text { Total } \\
\text { No. of } \\
\text { Cases }\end{array}$} \\
\hline & $\begin{array}{c}\text { Allowed } \\
\text { Adjudication } \\
\text { Decision }\end{array}$ & $\begin{array}{l}\text { Dismissed } \\
\text { Adjudication } \\
\text { Decision }\end{array}$ & $\begin{array}{c}\text { Allowed and } \\
\text { Dismissed part } \\
\text { of Adjudication } \\
\text { Decision }\end{array}$ & \\
\hline $\begin{array}{c}\text { As of } \\
\text { February } \\
2018\end{array}$ & 5 & 1 & 1 & 7 \\
\hline 2017 & 23 & 7 & 3 & 33 \\
\hline 2016 & 11 & 0 & 1 & 12 \\
\hline 2015 & 7 & 1 & 1 & 9 \\
\hline 2014 & 1 & 0 & 0 & 1 \\
\hline \multicolumn{4}{|c|}{ Total No. of Cases } & 62 \\
\hline
\end{tabular}

Table 2 shows the number of adjudication decision allowed and dismissed by the court. As of February 2018,7 adjudication cases were referred to the court. In 2017, a total of 33 dispute cases arising from payment problems were brought to court. Generally, most of the adjudication decisions were accepted by the court and there were only a few cases where the court had to adjust part of the results decided by the adjudicator. In 2015, there was an increase in the total number of cases referred to the court compared to 2014. Since the enforcement of the CIPAA in the Malaysian construction industry; 9 cases on payment security have been reported.

Nevertheless, there was 9 adjudication decision dismissed by the court within the period of April 2014 until February 2018. For instance, in Waterfront Celebration Village Sdn Bhd V Poh Huat Construction Sdn Bhd case, Waterfront Celebration Village set aside Adjudication decision as its denial of natural justice and excess jurisdiction as the adjudicator has considered the right to authorize a claim not made in the payment claim under Section 5 of the CIPAA 2012. Poh Huat Construction is not only claiming the amount listed as the debit note but has also been categorized in the list that needs to be deducted from a payment claim. Court held that the adjudicator's consideration is clearly contrary to the existing jurisdiction set out under Section 27 of the CIPAA 2012. The adjudicator has acted from a mandate passed by law. As such, it is found that the adjudicator has acted beyond its jurisdiction and allowed Waterfront Celebration Village's application to set aside adjudicator decision. A comparison made between adjudication decisions and the court decision on the 
same issues has shown that a majority of decisions made through adjudication were accepted by the court.

Table 3. Information regarding Claimants and Respondents acting in court cases and Plaintiffs and Defendants in adjudication

\begin{tabular}{|c|c|c|c|c|}
\hline $\begin{array}{c}\text { Party } \\
\text { Involved }\end{array}$ & $\begin{array}{c}\text { No. of } \\
\text { Claimant }\end{array}$ & $\begin{array}{c}\text { No. of } \\
\text { Respondent }\end{array}$ & $\begin{array}{c}\text { No. of } \\
\text { Plaintiff }\end{array}$ & $\begin{array}{c}\text { No. of } \\
\text { Defendant }\end{array}$ \\
\hline Employer & 17 & 17 & 17 & 17 \\
\hline $\begin{array}{c}\text { Main } \\
\text { Contractor }\end{array}$ & 31 & 28 & 28 & 31 \\
\hline $\begin{array}{c}\text { Sub- } \\
\text { Contractor }\end{array}$ & 13 & 14 & 14 & 13 \\
\hline Consultant & 0 & 3 & 3 & 0 \\
\hline Supplier & 1 & 1 & 1 & 1 \\
\hline
\end{tabular}

Table 3 shows the majority of Claimants who have brought their disputes to court are Main Contractors, followed by Employers and Sub-Contractors. There are 3 numbers of consultants acting as claimant, with a majority of them being Architects. Basically, most claimants in the High Court are defendants in the adjudication process as generally, claimants are the parties who are not satisfied with the adjudication decision and challenge the decision in High Court. Parties in disputes must have a contractual relationship in order to refer their disputes in court.

Unlike most applications before this Court for setting aside of an Adjudication Decision that are normally made by the Respondent who has to pay the sum stated in the Decision, here in the case of Syarikat Bina Darul Aman Berhad \& Anor V Government of Malaysia, there is no such application because the Respondent was not made to pay any sum to the Claimant. Likewise unlike most applications for enforcement of Adjudication decision that would be made by a successful Claimant, here there is none because the whole of the Claimant's Payment Claim was dismissed.

There was one case involves Supplier as a defendant which is between The Heavy Engineering Bhd V Innovative Synergy Solutions Sdn Bhd. The Heavy Engineering Bhd as main contractor applying to set aside Adjudication decision as Adjudicator had acted in excess of his jurisdiction and enforcement application by Innovative Synergy as a supplier to enforce the Adjudication Decision. Contractor not disputing the amount but merely challenging Adjudication decision not to proceed under adjudication instead in normal court or arbitration.

\section{Defence Outline}

The party who is not satisfied with an adjudication decision may appeal to the court to revise the decision. Typically, two or more parties dispute over the same matter. Thus, both sides will present their defence in any way possible to ensure that triumph and the final decision are in their favour.

Table 4. Provision section of CIPAA 2012 referred

\begin{tabular}{|c|c|c|c|c|c|c|c|}
\hline $\begin{array}{l}\text { Defence } \\
\text { Outline }\end{array}$ & Provision & 2014 & 2015 & 2016 & 2017 & 2018 & Total \\
\hline 1. Application & S.2 & 1 & 0 & 0 & 1 & 0 & 2 \\
\hline $\begin{array}{l}\text { 2. Fraud or } \\
\text { Bribery }\end{array}$ & S.15 (a) & 0 & 1 & 1 & 1 & 0 & 3 \\
\hline $\begin{array}{l}\text { 3. Denial of } \\
\text { Natural Justice }\end{array}$ & S.15 (b) & 0 & 4 & 10 & 22 & 5 & 41 \\
\hline \begin{tabular}{|l|l} 
4. Not Acted \\
Independently \\
or Impartially
\end{tabular} & S.15 (c) & 0 & 1 & 4 & 6 & 0 & 11 \\
\hline \begin{tabular}{|l|} 
5. Excess of \\
Jurisdiction \\
\end{tabular} & S.15 (d) & 0 & 4 & 9 & 26 & 5 & 44 \\
\hline \begin{tabular}{|l} 
6. Stay of \\
adjudication \\
decision
\end{tabular} & S.16 & 0 & 3 & 2 & 10 & 1 & 16 \\
\hline $\begin{array}{l}\text { 7. Jurisdiction of } \\
\text { Adjudicator }\end{array}$ & S.27 & 0 & 0 & 0 & 1 & 0 & 1 \\
\hline $\begin{array}{l}\text { 8. Enforcement of } \\
\text { Adjudication } \\
\text { decision as } \\
\text { Judgement }\end{array}$ & S. 28 & 0 & 5 & 10 & 22 & 2 & 39 \\
\hline $\begin{array}{l}\text { 9. Prohibition of } \\
\text { Conditional } \\
\text { Payment }\end{array}$ & S.35 & 0 & 1 & & 1 & 0 & 2 \\
\hline 7. Exemption & S. 40 & 0 & 1 & 0 & 0 & 0 & 1 \\
\hline
\end{tabular}

Table 4 indicates most provisions of CIPAA 2012 referred to court are Section 15 as the grounds in which an aggrieved party may apply to the High Court to set aside an adjudication decision which is improperly procured adjudication decision as Adjudicator had excess of his jurisdiction under section 15 (d), followed by Denial of Natural Justice under section 15 (b) and Section 28 to Enforce of Adjudication decision as Judgement. Section 16 of CIPAA explains the circumstances where a party may apply to the High Court for a stay of an adjudication decision; where (a) an application to set aside the adjudication decision under Section 15 has been made, or (b) the subject matter of the adjudication decision is pending final determination by arbitration or the court. Section 28 clarifies on the enforcement of adjudication decisions as judgement where a party may enforce an adjudication decision by applying to High Court for an order to enforce the adjudication decision as if it is a judgement or order of the High Court.

Section 2 provides the applicable provision of CIPAA 2012 as this Act applies to every construction contract made in writing relating to construction work carried out wholly or partly within the territory of Malaysia including a construction contract entered into by the Government. The UDA Holdings Bhd v Bisraya Construction Sdn Bhd case emerged as the first adjudication case referred to the court right after the implementation of CIPAA under section 2 . Retrospective statutory interpretations of non-payment

*Corresponding author: zulhabri@salam.uitm.edu.my**,quratulmazani@gmail.com * 
claims and rates disputes before 15 April 2014 were based on arbitration. However, since CIPAA came into force on 15 April 2014, the rules provide for whether the adjudicator has the jurisdiction to hear and decide disputes that arose before 15 April, 2014, whether there are express prescriptions in the Act on the limit of applicability of Act, whether the Act is to be applied retrospectively or prospectively, whether substantive rights would be affected by the retrospective application of the Act, whether the Act is applicable prospectively to only construction contracts made on or after operation of the Act, whether the Act is applicable retrospectively to all payment disputes provided that no litigation proceeding had commenced, and whether the Act is applicable to payment disputes under construction contracts which arose on or after the operation date of the contract regardless of when the contract was made. Court held it is the undoubted intention of Parliament that CIPAA applies to all construction contracts made in writing regardless of when those contracts were made so long as those construction contracts are to be carried out wholly or partly within the territory of Malaysia. Even construction contracts made by the Government fall within the purview of CIPAA.

\section{Conclusion}

The research proves the effectiveness of CIPAA in assisting payment disputes occurring in the Malaysian construction industry. Nonetheless, the number of adjudication cases intervened by the court has increased over the years, indicating that there is doubt about the decisions made by adjudicators. When a comparison between adjudicators' decisions to court decisions on the same issue was made, it was proven that a majority of decisions made by adjudicators were allowed by the court. AIAC (2018) reported that the enactment of the CIPAA 2012 resulted in the establishment of two specialist Construction Courts in the High Court of Kuala Lumpur and the High Court of Shah Alam on 1st April 2013 and the purpose of these Construction Courts has been to ensure greater efficiency in the handling of construction disputes by having judges in the courts who have experience in and are familiar with the construction industry. The Asian International Arbitration Centre (AIAC) is merely the administrative authority and cannot participate in whatever functions during enforcement and other adjudication-related court proceedings. For the avoidance of any doubt, the AIAC is in no position to support any party's motion. Many adjudication cases in the Malaysian construction industry involve the Main contractor and Employer as dispute parties with the intention of challenging adjudication decisions as there has been excess of jurisdiction pursuant to Section 15 (d) applied by appellants together with enforcement of adjudication decision under Section 28 applied by respondents.

\section{References}

1. T. Ramachandra, J.O. Rotimi, "Causes of Payment Problems in the New Zealand Construction Industry", Construction Economics and Building, vol. 15, no. 1, pp.43-55, 2015.

2. S.S. Judi, N. Mustaffa, R. Nayan, “A Framework for Combating Payment-Related Isuues (PRI) in the Malaysian Construction Industry," Journal of Built Environment, Technology and Engineering, vol. 2, pp. 112-132, 2017.

3. B. Raji, A.A. Mohamed, A.U. Oseni, "Reforming the Legal Framework for Construction Dispute Resolution in Nigeria: A Preliminary Literature Survey," International Business, Economics and Law, vol. 6, no. 4, pp. 87-95, 2015.

4. M.N. Azman, N. Dzulkalnine, Z.A Hamid, K.W. Bing, "Payment Issue in Malaysian Construction Industry: Contractors' Perspective," Jurnal Teknologi (Sciences \& Engineering), vol. 70, no. 1, pp. 57-63, 2014.

5. L.S. Chin, A.R. Hamid, "The practice of time management on construction project," Procedia Engineering 125, pp. 32-39, 2015.

6. M.K. Badroldin, A.R. Hamid, S.A. Raman, R. Zakaria, S.R. Mohandes, "Late payment practice in the Malaysian construction industry," Malaysian Journal of Civil Engineering 28 Special Issue (3), pp. 149-162, 2016.

7. S. Rajoo, "The Construction Industry Payment and Adjudication Act 2012 Comes into Operation," Press Release of Kuala Lumpur Regional Centre for Arbitration, 2014.

8. N. Ali, N.A. Ali. A, "Construction Industry Payment and Adjudication Act: Reducing Payment Default and Increasing Dispute Resolution Efficiency In Construction," Master Builder Journal 3rd Qtr 2006, 2016.

9. S.N. Jamalulil, Z. Ismail, "The Viability of Adjudication as an Alternative Dispute Resolution Method in the Malaysian Construction Contract," IEEE Colloquium on Humanities, Science and Engineering, 2014.

10. M.N. Azman, N. Dzulkalnine, Z.A. Hamid, K.A. Kamar, M.N. Nawi, "Payment Scenario in the Malaysian Construction Industry Prior to CIPAA" CIB World Building Congress Law and Dispute Resolution, pp. 105-114, 2013.

11. M.F. Ishak, S.A. Anuar, K. Alauddin, "Construction Industry Payment and Adjudication Act 2012: Perception of the Construction Parties in Mitigating the Payment Issues within the Construction Industry," International Conference on Innovation And Technology For Sustainable Built Environment, 2014.

12. M.A. Majid, "The Impact of the Construction Industry payment and Adjudication Act 2012 on

*Corresponding author: zulhabri@salam.uitm.edu.my**,quratulmazani@gmail.com * 
Government Contract Administration (2013)," [Accessed:10 May, 2018]

13. N.N. Din, Z. Ismail, "Construction Industry Payment and Adjudication Act (CIPAA) Remedying Payment Issues: CIDB G7 Contractor's Perspective," Journal of Technology Management and Business, vol. 1, no. 1, pp. 21-38, 201 